\section{P94 DO HEALTHCARE PROFESSIONALS HAVE SUFFICIENT KNOWLEDGE OF INHALER TECHNIQUES IN ORDER TO EDUCATE THEIR PATIENTS EFFECTIVELY IN THEIR USE?}

doi:10.1136/thx.2010.150979.45

${ }^{1} \mathrm{M}$ Baverstock, ${ }^{2} \mathrm{~N}$ Woodhall, ${ }^{1} \mathrm{~V}$ Maarman. ${ }^{1}$ Milton Keynes Hospital NHS Foundation Trust, Milton Keynes, England; ${ }^{2}$ NHS Milton Keynes Primary Care Trust, Milton Keynes, England

Introduction and objectives Inhalers are widely used in the treatment of asthma and chronic obstructive pulmonary disease (COPD). For patients to gain maximum benefit they need to be educated by competent healthcare professionals (HCPs) whose own competence meets accepted standards. This study looked at HCPs ability to use the commonly prescribed metered dose inhaler (pMDI).

Methods 150 Healthcare professionals (74 Primary Care Trust; 76 Acute Trust) were asked to demonstrate how they would selfadminister a pMDI placebo Inhaler. The Group included hospital doctors, hospital nurses, general practitioners, pratice nurses, hospital and community pharmacy staff. Each professional was marked against a standard set by the manufacturer and Education for Health UK. ${ }^{1}$ They were also asked to demonstrate the correct inspiratory flow rate using the In-check dial device. ${ }^{2}$

Results Of the 150 HCPs assessed only 11 (7\%) could demonstrate all the recognised steps in administration including assessment of inspiratory flow using the in-check device (Abstract P94 Figure 1). $113(75 \%)$ of the HCPs said they were involved in the teaching of inhaler technique. Of these 113, 11(9\%) could demonstrate all the recognised Steps ( $\mathrm{n}=10$ PCT $\mathrm{n}=1$ acute trust). Of the 150, 72 $\mathbf{( 4 8 \% )}$ were prescribers or were involved in prescribing. $94(63 \%)$ had received some training on Inhaler technique in the past of which $64(67 \%)$ said the training took place more than a year before.

\section{Number of HCP, who demonstrated all 7 steps correctly \& I or correct inspiratory flow rate using the in Check Dial}

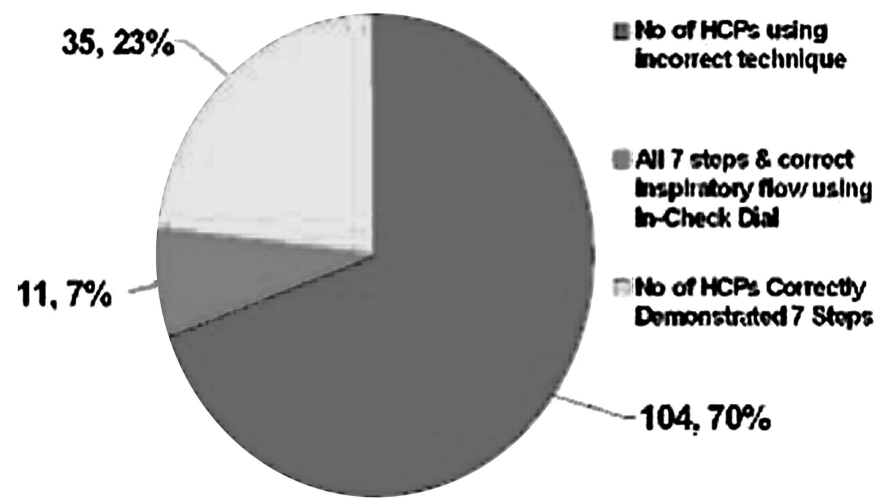

Abstract P94 Figure 1 Number of HCP's who demonstrated all 7 steps correctly \&/ or correct inspiratory flow rate using the In-Check Dial.

Conclusion If we are going to adequately educate our patients with regard to their inhaler usage we as HCPs need to be competent in how each device works. Incorrect teaching and assessment will increase use of healthcare resources, waste medication, and mean worsening symptoms and poor control of airways disease for our patients.

\section{REFERENCES}

1. Education for Health. Simply Devices: A practical handbook for health professionals. Warwick. Education for Health 2006.

2. In-Check Dial-Clement Clarke International. http://www.clementclarke.com/products/ inspiratory flow/http//www.clementclarke.com/products/inspiratory flow/incheck_dial/index.html.

\section{P95 OXYGEN DELIVERY IN AN ACUTE HOSPITAL SETTING}

doi:10.1136/thx.2010.150979.46

J Maycock, K Ellis, P Mullholland, L Bate, V Sadananda, D Nazareth, S Agarwal, P Stockton. St. Helens and Knowsley Teaching Hospitals NHS Trust, Prescot, UK

Background Oxygen is one of the most widely used drugs in secondary care. The National Patient Safety Agency (NPSA), UK issued guidance ${ }^{1}$ ensuring safer management of oxygen delivery. Many individuals do not see oxygen as a drug and hence prescribing oxygen within most Trusts has been poor. This study assesses Health Care Professionals (HCPs) knowledge of the basic principles of oxygen delivery in an acute medical setting, to ensure the safe use of oxygen and to inform a Trust Oxygen Steering Group in order to target educational sessions appropriately.

Method A questionnaire listing 10 common scenarios, based on the BTS guidelines ${ }^{2}$ was administered to a random selection of doctors and nurses (Abstract P95 Table 1). Responses were evaluated by a panel of Respiratory Physicians. For each scenario respondents indicated whether they would give oxygen, appropriate target saturations, delivery device to be used and the flow rate.

Results 139 HCPs completed the questionnaire (41\% junior doctors, $59 \%$ nurses). The results are summarised below. Common mistakes included

1. The use of non-rebreather mask instead of bag and mask in cardiac arrest situations

2. Failing to identify the use of high flow oxygen in the conservative management of patients with a pneumothorax and

3. Failing to recognize the use of Venturi masks in COPD patients.

Abstract P95 Table 1 Correct responses (\%) to oxygen delivery, target saturations, delivery devices and flow rate

\begin{tabular}{|c|c|c|c|c|c|}
\hline Scenario & $\begin{array}{l}\text { D-doctor } \\
\text { N-nurse }\end{array}$ & $\begin{array}{l}02 \\
\text { delivery }\end{array}$ & $\begin{array}{l}\text { Target } \\
\text { Sats }\end{array}$ & Device & $\begin{array}{l}\text { Flow } \\
\text { rate }\end{array}$ \\
\hline \multirow[t]{2}{*}{ Cardiac arrest (GI bleed) } & $D$ & 100 & 60 & 46 & 91 \\
\hline & $\mathrm{N}$ & 98 & 45 & 39 & 84 \\
\hline \multirow[t]{2}{*}{ Severe COPD, LTOT, Cardiac arrest } & $D$ & 96 & 7 & 53 & 86 \\
\hline & $\mathrm{N}$ & 95 & 2 & 33 & 79 \\
\hline \multirow{2}{*}{$\begin{array}{l}\text { Primary pneumothorax } \\
\text { managed conservatively }\end{array}$} & $\mathrm{D}$ & 54 & 35 & 7 & 7 \\
\hline & $\mathrm{N}$ & 40 & 21 & 1 & 2 \\
\hline \multirow{2}{*}{$\begin{array}{l}\text { Severe COPD, rim of pneumothorax, } \\
\text { conservative Rx, Sats } 94 \% R A\end{array}$} & $\mathrm{D}$ & 81 & 11 & 81 & 81 \\
\hline & $\mathrm{N}$ & 80 & 7 & 80 & 80 \\
\hline \multirow{2}{*}{$\begin{array}{l}\text { Acute exacerbation of asthma, } \\
\text { Sats } 89 \% \text { on room air }\end{array}$} & $D$ & 100 & 42 & 91 & 88 \\
\hline & $\mathrm{N}$ & 98 & 37 & 99 & 82 \\
\hline \multirow{2}{*}{$\begin{array}{l}\text { Severe community acquired } \\
\text { pneumonia, Sats } 87 \% \text { on room air }\end{array}$} & $D$ & 100 & 33 & 79 & 79 \\
\hline & $\mathrm{N}$ & 96 & 9 & 85 & 82 \\
\hline \multirow{2}{*}{$\begin{array}{l}\text { COPD, Carcinoma bronchus, } \\
\text { Sats } 90 \% \text { on room air }\end{array}$} & $D$ & 100 & 11 & 40 & 91 \\
\hline & $\mathrm{N}$ & 98 & 7 & 27 & 95 \\
\hline \multirow{2}{*}{$\begin{array}{l}\text { Exacerbation COPD, LTOT, } \\
\text { Sats } 98 \% \text { on a non-rebreather }\end{array}$} & $D$ & 77 & 32 & 58 & 47 \\
\hline & $\mathrm{N}$ & 74 & 17 & 30 & 21 \\
\hline \multirow{2}{*}{$\begin{array}{l}\text { Exacerbation COPD, Sats } 86 \% \\
(2 \mathrm{l} / \mathrm{min}) \text {, usual Sats } 88 \%(\mathrm{LTOT})\end{array}$} & $\mathrm{D}$ & 88 & 46 & 28 & 19 \\
\hline & $\mathrm{N}$ & 84 & 50 & 20 & 18 \\
\hline \multirow{2}{*}{$\begin{array}{l}\text { Infective exacerbation of COPD, } \\
\text { Sats } 84 \% \text { on room air }\end{array}$} & $D$ & 98 & 32 & 61 & 44 \\
\hline & $\mathrm{N}$ & 94 & 24 & 44 & 35 \\
\hline
\end{tabular}

